\title{
Diagnosis dan Tatalaksana Sindrom Hepatorenal
}

\author{
Jovanca G. Timbul, ${ }^{1}$ Cerelia E. C. Sugeng, ${ }^{2}$ Bradley J. Waleleng ${ }^{2}$
}

\author{
${ }^{1}$ Program Studi Pendidikan Dokter Fakultas Kedokteran Universitas Sam Ratulangi, \\ Manado, Sulawesi Utara, Indonesia \\ ${ }^{2}$ Bagian Ilmu Penyakit Dalam Fakultas Kedokteran Universitas Sam Ratulangi Manado, \\ Sulawesi Utara, Indonesia \\ Email: jovancatimbul27@gmail.com
}

\begin{abstract}
Hepatorenal syndrome (HRS) is known as a complication of cirrhosis. Currently, there are no specific laboratory tests to diagnose HRS while liver transplantation, as the definitive therapy, is still problematic due to the poor prognosis and long waiting lists. HRS is typically associated with poor prognosis, with a mortality rate of more than $95 \%$. Without liver transplantation or appropriate vasoconstrictor therapy, the life expectancy was less than 2 weeks. This study was aimed to describe the diagnosis and management of the hepatorenal syndrome. The study design was literature review. Published literature was obtained from three databases: PubMed, ScienceDirect, and Google Scholar. All articles that met the inclusion and exclusion criteria were included in this study. According to five studies regarding the diagnosis, both the incidence and mortality rate of HRS was relatively high $(38.1 \%$ of all acute kidney injury cases and $64.5 \%$, respectively), even with in-hospital therapy. Five other studies analyzed the management of HRS. It was reported that the mean age of the youngest SHR patients was 53.3 years and the mean oldest age was 65 years. The male gender predominated in all studies (50-79\%). In conclusion, the latest revision classified HRS into three groups: HRS-AKI, HRSAKD, and HRS-CKD. Pharmacological therapies for HRS including terlipressin, octreotide, midodrine, albumin, pentoxifylline, and various combinations of these therapies.
\end{abstract}

Keywords: Hepatorenal Syndrome, Diagnosis of HRS, Management of HRS

\begin{abstract}
Abstrak: Komplikasi dari sirosis hati antara lain sindrom hepatorenal (HRS). Sampai saat ini pemeriksaan laboratorium secara spesifik untuk mendiagnosis HRS belum ada. Transplantasi hati secara teori merupakan terapi yang tepat namun masih merupakan masalah utama karena prognosisnya buruk dan daftar tunggu yang lama di pusat transplantasi. Prognosis HRS umumnya buruk dengan angka mortalitas lebih dari 95\%, jika tidak melalui transplantasi hati atau terapi vasokonstriktor yang tepat maka rerata angka harapan hidup pasien kurang dari 2 minggu. Penelitian ini bertujuan untuk mengetahui diagnosis dan tatalaksana HRS. Jenis penelitian ialah literature review dengan menggunakan tiga database yaitu PubMed, Science Direct, dan Google Scholar sesuai dengan kriteria inklusi dan eksklusi yang ada. Berdasarkan lima literatur penegakan diagnosis HRS, diketahui insidensi dan angka kematian HRS relatif tinggi (38,1\% dari seluruh kasus acute kidney injury (AKI) dan angka kematian 64,5\%), meskipun telah mendapatkan terapi di rumah sakit. Lima literatur lainnya tentang tatalaksana SHR, diketahui rerata (mean) usia termuda pasien HRS 53,3 tahun dan rerata (mean) usia tertua 65 tahun, dan yang mendominasi sampel penelitian ialah jenis kelamin laki-laki (50-79\%). Simpulan penelitian ini ialah revisi terbaru menunjukkan HRS diklasifikasikan menjadi tiga kelompok: HRS-AKI, HRS-AKD, dan HRS-CKD. Terapi medikamentosa untuk HRS di antaranya terlipressin, oktreotida, midodrine, albumin, pentoxifylline, serta berbagai kombinasi dari terapi tersebut.
\end{abstract}

Kata kunci: sindrom hepatorenal, diagnosis HRS, tatalaksana HRS 


\section{PENDAHULUAN}

Tahun 2016 sirosis hati ( $\mathrm{SH})$ termasuk kedalam 20 penyebab kematian terbanyak di dunia dengan prevalensi $2,2 \%$, total kumulatif kematian $56 \%$ dan insidens 16.8 per100.000 penduduk, berdasarkan data World Health Organization. ${ }^{1}$ Pada penelitian tahun 2015 di RSUP Prof. Dr. R. D. Kandou Manado terdapat 95 pasien sirosis hati periode Agustus 2012 - Agustus 2014. ${ }^{2}$

Komplikasi dari sirosis hati di antaranya sindrom hepatorenal (SHR) atau hepatorenal syndrome (HRS). ${ }^{3}$ Sindrom hepatorenal adalah kegagalan faal ginjal yang terjadi pada pasien dengan penyakit hati berat (akut maupun kronik) tanpa disertai kelainan patologi ginjal. Sindrom ini ditandai dengan gangguan fungsi ginjal, perubahan fungsi kardiovaskular, aktivitas berlebih dari saraf simpatis dan sistem renin angiotensin, sehingga terjadi vasokonstriksi ginjal yang berat dan akan mengarah pada penurunan laju filtrasi glomerulus (LFG). ${ }^{4}$

Pemeriksaan laboratorium yang spesifik untuk HRS belum ada. Penyakit ini biasanya didiagnosis dengan mengevaluasi LFG dan menyingkirkan penyebab gagal ginjal prerenal, glomerulonephritis, nekrosis tubu-lar akut, dan nefrotoksisitas karena obat. ${ }^{4}$ Secara klinis HRS dibagi atas dua tipe yaitu HRS tipe 1 dan HRS tipe 2. Sindrom hepatorenal tipe 1 ditandai dengan gangguan progresif fungsi ginjal dan penurunan klirens kreatinin secara bermakna dalam 1-2 minggu, sedangkan tipe 2 ditandai dengan penurunan filtrasi glomerulus dengan peningkatan serum kreatinin. ${ }^{4}$

Penatalaksanaan HRS terdiri dari penatalaksanaan umum, penatalaksanaan medikamentosa dan tindakan invasif. Penatalaksanaan umum terdiri dari: 1) Terapi suportif berupa diet tinggi kalori dan rendah protein; 2) Koreksi keseimbangan asam basa; 3) Hindari pemakaian obat anti inflamasi non steroid (OAINS); dan 4) Peritonitis bakterial spontan pada $\mathrm{SH}$ harus diatasi dalam rangka mencegah terjadinya HRS. $^{4}$ Tatalaksana dengan menggunakan vasokonstriktor perifer yang dikombinasi dan albumin intravena dapat memperbaiki fungsi ginjal, akan tetapi transplantasi hati secara teori merupakan terapi yang tepat untuk penderita HRS yang dapat menyembuhkan baik penyakit hati maupun disfungsi ginjalnya. Namun tindakan transplantasi ini tetap merupakan masalah utama mengingat prognosis yang buruk dan daftar tunggu yang lama untuk tindakan tersebut di pusat transplantasi. ${ }^{5}$ Prognosis HRS umumnya buruk dengan angka mortalitas lebih dari 95\% dan survival rerata kurang dari 2 minggu, dan tanpa transplantasi hati atau terapi vasokonstriksi yang tepat rerata angka harapan hidup pasien kurang dari 2 minggu. ${ }^{4}$

Berdasarkan latar belakang yang telah diuraikan maka penulis tertarik untuk membahas berbagai informasi ilmiah mengenai diagnosis dan tatalaksana HRS.

\section{METODE PENELITIAN}

Penelitian ini dilakukan pada bulan September-November 2020. Jenis penelitian ini ialah literature review. Data penelitian yang digunakan ialah literatur - literatur dari tiga database yaitu Science Direct, PubMed, dan Google Scholar. Kata kunci yang digunakan dalam pencarian literatur yaitu diagnosis dan tatalaksana dan "sindrom hepatorenal" dan kata kunci dalam Bahasa Inggris diagnostic OR diagnosis AND treatment OR therapy AND "hepatorenal syndrome". Kriteria inklusi dari penelitian ini ialah populasi pasien SHR, dengan intervention terapi yang diberikan, comparators jenis obat, bentuk, atau cara pemberian yang berbeda, dan jenis penelitian case control, cohort study, parallel group, retrospective cohort study, randomized control and trial, retrospective study, systematic review, dan meta-analysis. Tahun publikasi 2015 sampai 2020 serta berbahasa Inggris dan Indonesia. Kriteria eksklusi yakni tatalaksana SHR tindakan invasif dan literatur yang tidak tersedia fulltext.

\section{HASIL PENELITIAN}

Berdasarkan hasil pencarian literatur, didapatkan sebanyak 326 literatur menggunakan PubMed, 1.853 menggunakan Science Direct, 133 menggunakan Google Scholar $(\mathrm{n}=2.312)$ yang sesuai dengan kata 
kunci. Dari hasil pencarian yang didapatkan kemudian dilakukan skrining berdasarkan judul yang sesuai didapatkan 424 literatur $(n=424)$. Sebanyak 424 literatur disaring berdasarkan abstrak dan ketersediaan full text sehingga tersisa 113 literatur full text $(\mathrm{n}=113)$, kemudian disaring kembali berdasarkan kriteria inklusi dan eksklusi, dan didapatkan 10 literatur $(\mathrm{n}=10)$.

Setelah melalui tahap seleksi studi, didapatkan 10 literatur yang memenuhi kriteria inklusi dan eksklusi. Sebanyak 5 literatur digunakan untuk menjawab rumusan masalah mengenai diagnosis HRS yang ditampilkan pada Tabel 1. Lima literatur lainnya untuk menjawab rumusan masalah mengenai tatalaksana HRS dan diidentifikasi berdasarkan analisis PICOS framework yang ditampilkan pada Tabel 2 .

Tabel 1. Hasil kajian literatur mengenai diagnosis HRS

\begin{tabular}{|c|c|c|c|}
\hline No & Penulis dan Judul & $\begin{array}{c}\text { Metode } \\
\text { Penelitian }\end{array}$ & Hasil Penelitian \\
\hline 1 & $\begin{array}{l}\text { Jian Xiong et al (2019). } \\
\text { Evaluation of the criteria } \\
\text { of hepatorenal syndrome } \\
\text { tand ype of acute kidney } \\
\text { injury in patients with } \\
\text { cirrhosis admitted to ICU }\end{array}$ & Case control & $\begin{array}{ll}- & \text { Insiden AKI 73,0\%, terdiri dari HRS sebesar 38,1\%. } \\
- & \text { Kematian rumah sakit secara keseluruhan } 64,5 \% \\
- & \text { Angka kematian di rumah sakit dan kematian dalam } 180 \\
\text { hari tidak berbeda bermakna antara pasien dengan HRS- } \\
\text { AKI stadium 1-3. }\end{array}$ \\
\hline 2 & $\begin{array}{l}\text { Juan G Acevedo et } \\
\text { al(2017). }{ }^{7} \\
\text { Hepatorenal syndrome: } \\
\text { Update on diagnosis and } \\
\text { therapy }\end{array}$ & $\begin{array}{l}\text { Systematic } \\
\text { review tanpa } \\
\text { meta-analisis }\end{array}$ & $\begin{array}{l}\text { Kriteria diagnostik HRS menurut kriteria ICA-AKI adalah } \\
\text { sebagai berikut: } \\
\text { - Diagnosis sirosis dan asites } \\
\text { - } \text { Diagnosis AKI menurut kriteria ICA-AKI } \\
\text { - } \text { Tidak ada respon setelah } 2 \text { hari berturut-turut } \\
\text { penghentian diuretik dan ekspansi volume plasma } \\
\text { dengan albumin ( } \mathrm{g} / \mathrm{kg} \text { berat badan) } \\
\text { - } \text { Tidak adanya syok } \\
\text { - } \\
\text { Tidak ada penggunaan obat nefrotoksik saat ini atau } \\
\text { baru-baru ini (obat antiinflamasi non steroid, } \\
\text { aminoglikosida, media kontras beryodium, dll.) } \\
\text { Tidak ada tanda makroskopik dari cedera ginjal } \\
\text { struktural, yang didefinisikan sebagai tidak adanya } \\
\text { proteinuria (> 500 mg / hari), tidak adanya } \\
\text { mikrohematuria (> 50 sel darah merah per bidang } \\
\text { kekuatan tinggi) dan temuan normal pada USG ginjal. }\end{array}$ \\
\hline 3 & $\begin{array}{l}\text { Douglas A Simonetto et } \\
\text { al (2020). } \\
\text { Hepatorenal syndrome: } \\
\text { pathophysiology, diag- } \\
\text { nosis, and management }\end{array}$ & $\begin{array}{l}\text { Systematic } \\
\text { review tanpa } \\
\text { meta-analisis }\end{array}$ & 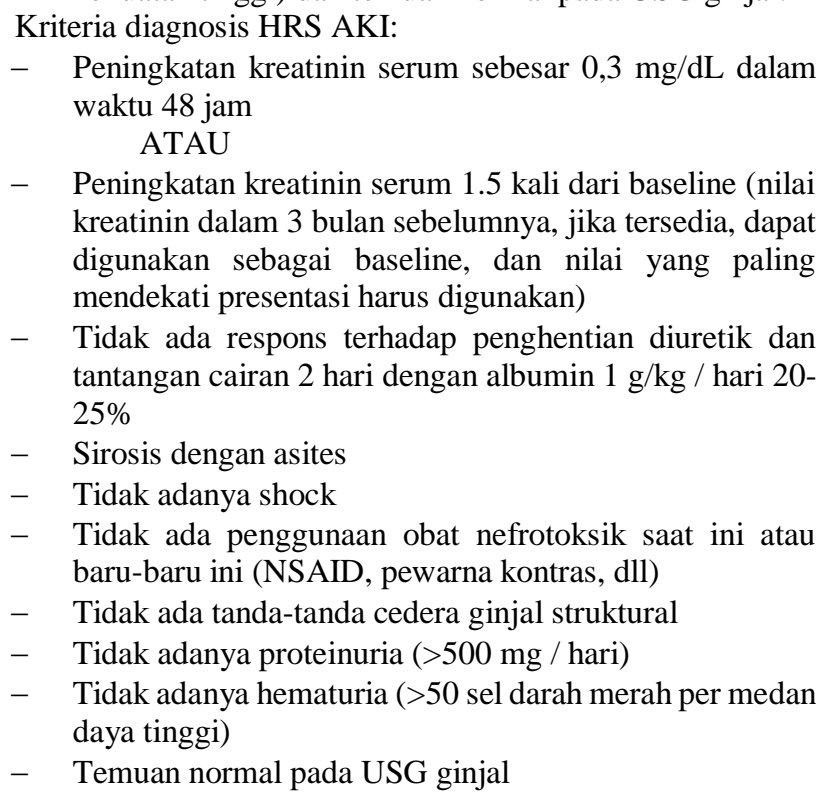 \\
\hline & & & Kriteria diagnosis HRS-AKD: \\
\hline
\end{tabular}


Angelo Zambam de Mattos et al (2016). ${ }^{9}$ Hepatorenal syndrome: Current concepts related to diagnosis and management

Paolo Angeli, et al (2019). ${ }^{10}$

News in pathophysiology, definition and classification of hepatorenal syndrome: A step beyond the International Club of Ascites (ICA) consensus docu-ment
Systematic review tanpa meta-analisis

Systematic review tanpa meta-analisis
- Perkiraan laju filtrasi glomerulus $<60 \mathrm{~mL} / \mathrm{min} / 1,73 \mathrm{~m} 2$ selama $<3$ bulan jika tidak ada penyebab potensial penyakit ginjal lainnya

- Persentase peningkatan kreatinin serum $<50 \%$ menggunakan nilai terakhir kreatinin serum rawat jalan yang tersedia dalam waktu 3 bulan sebagai nilai dasar

Kriteria diagnosis HRS-CKD:

- Perkiraan laju filtrasi glomerulus $<60 \mathrm{~mL} / \mathrm{min} / 1,73 \mathrm{~m} 2$ selama $>3$ bulan tanpa adanya penyebab potensial penyakit ginjal lainnya

- Diagnosis HRS didasarkan pada peningkatan konsentrasi kreatinin hingga $>1,5 \mathrm{mg} / \mathrm{dL}$ pada pasien dengan sirosis dan asites yang tidak pulih setelah 48 jam suspensi diuretik dan ekspansi volume dengan albumin ( $1 \mathrm{~g} / \mathrm{kg}$ / hari hingga maksimum $100 \mathrm{~g} / \mathrm{hari})$.

- Diagnosis memerlukan pengecualian syok, penggunaan obat nefrotoksik baru-baru ini, dan penyakit ginjal parenkim, seperti yang ditunjukkan oleh protein urin 24 jam> $500 \mathrm{mg}$, sedimen urin dengan jumlah eritrosit $>50$ sel per medan daya tinggi, atau kelainan USG ginjal

- International Club of Ascites mengusulkan revisi berupa peningkatan kreatinin $\geq 0,3 \mathrm{mg} / \mathrm{dL}$ (atau $\geq 50 \%$ ) dari nilai dasar.

HRS AKI:

Peningkatan mutlak dalam kreatinin serum $(\mathrm{sCr}) \geq 0,3 \mathrm{mg} / \mathrm{dl}$ dalam 48 jam

dan/atau

Output urin $\leq 0,5 \mathrm{ml} / \mathrm{kgBB} \geq 6$ jam

atau

Persentase peningkatan $\mathrm{sCr} \geq 50 \%$ menggunakan nilai terakhir sCr rawat jalan yang tersedia dalam 3 bulan sebagai nilai dasar

HRS AKD:

eGFR $<60 \mathrm{ml} / \mathrm{mnt}$ per $1,73 \mathrm{~m} 2$ selama $<3$ bulan tanpa adanya penyebab (struktural) lainnya

atau

Persen peningkatan $\mathrm{sCr}<50 \%$ menggunakan nilai terakhir $\mathrm{sCr}$ rawat jalan yang tersedia dalam 3 bulan sebagai nilai dasar

HRS CKD:

eGFR $<60 \mathrm{ml} / \mathrm{mnt}$ per $1,73 \mathrm{~m} 2$ selama $\geq 3$ bulan tanpa adanya penyebab (struktural) lainnya

Tabel 2. Analisis PICOS Framework tatalaksana sindrom hepatorenal

\begin{tabular}{|c|c|c|c|c|c|c|}
\hline No & $\begin{array}{c}\text { Penulis } \\
\text { dan Judul }\end{array}$ & Population & Intervention & Comparator & Outcome & $\begin{array}{l}\text { Study } \\
\text { Design }\end{array}$ \\
\hline 1. & $\begin{array}{l}\text { Thomas D } \\
\text { Boyer et al } \\
(2015) .{ }^{11} \\
\text { Terlipres- } \\
\text { sin plus al- } \\
\text { bumin is } \\
\text { more effec- } \\
\text { tive than } \\
\text { albumin } \\
\text { alone } \\
\text { in impro- } \\
\text { ving renal } \\
\text { function in } \\
\text { patients } \\
\text { with }\end{array}$ & $\begin{array}{l}196 \text { pasien di } \\
\text { Amerika Seri- } \\
\text { kat } \\
\text { Dibagi dalam } 2 \\
\text { kelompok: } \\
\text { Terlipressin } 97 \\
\text { pasien; Laki- } \\
\text { laki } 52(53,6 \%) \\
\text { dan perempuan } \\
45 \text { (46,4\%) de- } \\
\text { ngan rerata usia } \\
55,8 \text { tahun. } \\
\text { Plasebo } 99 \text { pa- } \\
\text { sien; laki- laki } \\
67 \quad(67,67 \%)\end{array}$ & $\begin{array}{l}97 \text { pasien dibe- } \\
\text { rikan terapi ter- } \\
\text { lipressin secara } \\
\text { intravena } \\
\text { sebanyak } 1 \mathrm{mg} \\
\text { setiap } 6 \text { jam }(4 \\
\text { mg per hari) } \\
\text { selama } 14 \text { hari. }\end{array}$ & $\begin{array}{l}99 \text { pasien di- } \\
\text { berikan terapi } \\
\text { plasebo seca- } \\
\text { ra intravena } \\
\text { setiap } 6 \text { jam } \\
\text { selama } 14 \\
\text { hari. }\end{array}$ & $\begin{array}{l}\text { Confirmed Hepatorenal Syndrome } \\
\text { Reverse (CHRSR) diamati pada } 19 \\
\text { dari } 97 \text { pasien }(19,6 \%) \text { yang } \\
\text { menerima terlipressin vs } 13 \text { dari } \\
99 \text { pasien }(13,1 \%) \text { yang menerima } \\
\text { plasebo }(\mathrm{p}=, 22) \text {. Pembalikan HRS } \\
\text { dicapai pada } 23 \text { dari } 97(23,7 \%) \\
\text { pasien yang menerima terlipressin } \\
\text { vs } 15 \text { dari } 99(15,2 \%) \text { y menerima } \\
\text { plasebo (p=,13). SCr menurun } 1,1 \\
\text { mg/dL pada pasien yang mene- } \\
\text { rima terlipressin dan hanya } 0,6 \text { mg } \\
\text { dL pada pasien yang menerima } \\
\text { plasebo (p<001). Penurunan SCr } \\
\text { dan kelangsungan hidup berkore- }\end{array}$ & $\begin{array}{l}\text { Parallel } \\
\text { group }\end{array}$ \\
\hline
\end{tabular}




$\begin{array}{ll}\text { cirrhosis } & \text { dan perempuan } \\ \text { and hepa- } & 32 \quad(32.32 \%) \\ \text { torenal } & \text { dengan mean } \\ \text { syndrome } & \text { (rerata) usia } \\ \text { type 1 } & 54,8 \text { tahun. }\end{array}$

2. Marta

Cavallin et al (2015). ${ }^{12}$

Terlipressin plus al-

bumin

versus

midodrine

and octreo-

tide plus al-

bumin in

the treat-

ment of

hepatorenal

syndrome:

a randomi-

zed trial

49 pasien di

Italia

Dibagi dalam 2

kelompok:

Terlipressin

(TERLI) 27

pasien; Laki-

laki 21

$(77,78 \%)$ dan

perempuan 6

$(22,22 \%)$

dengan mean

(rerata) usia 60

tahun

Midodrine dan

Octreotide

(MID/OCT) 21

pasien; Laki-

laki

11

$(52,38 \%)$ dan

perempuan 10

$(47,62 \%)$

dengan rerata

usia 65 tahun

3. Marta 71 pasien di

Cavallin et Itali

$\operatorname{al}(2016) .{ }^{13}$

Terlipres-

Dibagi dalam 2

kelompok:

sin given by

conti-nuous

intra-

venous

infusion

versus

intravenous

boluses in

the treat-

ment of

hepatorenal

syndrome:

a randomi-

zed control-

led study

Terlipressin

infusi (TERLI-

INF) 34 pasien;

Laki - laki 24

(70,58\%) dan

perempuan 10

$(29,42 \%)$

dengan mean

(rerata) usia

57,41 tahun.

Terlipressin

bolus (TERLI-

BOL) 37 pasi-

en; Laki-laki 24

$(64,86 \%)$ dan

perempuan 13

$(35,14 \%)$

dengan rerata

usia $\quad 59,41$

tahun.

4. Jonathan G. 12 pasien di 6 pasien diberiStine et al Rumah Sakit kan terapi pen(2018). ${ }^{14} \quad$ Universitas

Treatment Virginia

of type-1 Dibagi dalam 2

hepatorenal

kelompok:

toxifylline 400

mg tiga kali dan

6 pasien dibe-

rikan terapi

AMO.

AMO selama

14 hari.
21 pasien diberikan terapi midodrine secara oral sebanyak 7,5 mg tiga kali sehari bersama dengan octreotide secara subkutan sebanyak 100 $\mu \mathrm{g}$ tiga kali sehari. lasi $\left(\mathrm{r}^{2}=.882 ; \mathrm{p}<.001\right) . \quad$ Pasien kelompok terlipressin memiliki lebih banyak kejadian iskemik. Terlipressin plus albumin berhubungan dengan peningkatan fungsi ginjal pada pasien dengan sirosis dan HRS-1

Ada tingkat pemulihan fungsi ginjal yang lebih tinggi secara bermakna dalam kelompok TERLI $(19 / 27, \quad 70,4 \%)$ dibandingkan kelompok MID/OCT (6/21,

$28.6 \%), \quad \mathrm{p}=0,01$. Peningkatan fungsi ginjal dan penyakit hati dikaitkan dengan kelangsungan hidup yang lebih baik.

Terlipressin plus albumin dapat meningkatkan perbaikan fungsi ginjal $(70,4 \%)$ pada pasien sirosis dan HRS.
37 pasien Tingkat efek samping lebih rendah diberikan terapi terlipressin dalam bentuk bolus secara intravena sebanyak 0,5 mg setiap 4 jam selama maksimal 15 hari. pada kelompok TERLI-INF (35,29\%) dibandingkan pada kelompok TERLI-BOL $(62,16 \%$, $\mathrm{P}<0,025)$. Tingkat respons terhadap pengobatan lengkap dan parsial tidak berbeda signifikan antara kedua kelompok $(76,47 \%$ versus 64,85\%; nilai $\mathrm{P}$ tidak signifikan). Rata-rata dosis efektif terlipresin harian lebih rendah pada kelompok TERLI-INF dibandingkan pada kelompok TERLI-BOL $\quad(2,23 \pm 0,65 \quad$ vs $3,51 \pm 1,77 \mathrm{mg} /$ hari; $\mathrm{P}<0,05)$.
Retrospe ctive cohort study

Retrospe ctive cohort study
Rerata skor Model for End-Stage Liver Disease (MELD) ialah $26,5 \pm 7,4$ untuk perempuan dan $58,3 \%$ untuk laki-laki. Keseluruhan kohort 30- dan kelangsungan hidup 180 hari adalah $58,3 \%$ dan 33,3\% masingmasing. Resolusi HRS-1 (16,7\% vs $16,7 \%, \mathrm{p}=1.000)$, pengobatan
Retrospe ctive study with $\quad$ Pentoxifylline

pentoxifyl- Albumin, 


\begin{tabular}{|c|c|c|c|c|c|}
\hline 5. & $\begin{array}{l}\text { Shahid } \\
\text { Sarwar dan } \\
\text { Anwaar A. } \\
\text { Khan } \\
(2016) .^{15} \\
\text { Hepatorena } \\
1 \text { syndrome: } \\
\text { response to } \\
\text { terlipressin } \\
\text { and albu- } \\
\text { min and its } \\
\text { determi- } \\
\text { nants }\end{array}$ & $\begin{array}{l}\text { Octreotide dan } \\
\text { Midodrine } \\
\text { (AMO) } \\
\text { pasien; Laki- } \\
\text { laki 3 (50\%) } \\
\text { dan perempuan } \\
3(50 \%) \text { dengan } \\
\text { rerata usia } 57 \\
\text { tahun. } \\
\text { Plasebo } \\
\text { AMO 6 pasien; } \\
\text { Laki-laki } 4 \\
\text { (66,67\%) dan } \\
\text { perempuan } 2 \\
(33,33 \%) \\
\text { dengan rerata } \\
\text { usia 60,8 tahun. } \\
24 \text { pasien di } \\
\text { Rumah Sakit } \\
\text { The Doctors } \\
\text { and Medical } \\
\text { Center, } \\
\text { Pakistan. } \\
\text { Laki-laki } 19 \\
\text { (79\%) } \\
\text { perempuan } 5 \\
(21 \%) \text { dangan } \\
\text { rerata usia } 53.3 \\
\text { tahun. }\end{array}$ & $\begin{array}{l}24 \text { pasien dibe- } \\
\text { rikan terapi ter- } \\
\text { lipressin } \\
\text { sebanyak } 2 \mathrm{mg} \\
\text { per hari }\end{array}$ & $\begin{array}{l}\text { Respon menyeluruh terhadap } \\
\text { terlipressin/albumin terlihat pada } \\
14(58,3 \%) \text { pasien, } 7 \text { (29,2\%) } \\
\text { mencapai respon parsial dengan } \\
\text { penurunan kreatinin }>25 \% \text { semen- } \\
\text { tara } 3(12,5 \%) \text { tidak memberi } \\
\text { respon. Penurunan serum kreatinin } \\
\text { saat diagnosis (nilai P 0,003), tidak } \\
\text { adanya hiperkalemia (nilai p } \\
\text { 0,005) dan tidak adanya vena } \\
\text { portal trombosis (nilai p 0,05) } \\
\text { berhubungan dengan respons } \\
\text { terhadap pengobatan pada pasien } \\
\text { HRS. Kreatinin serum dasar (p } \\
\text { 0,003) adalah prediktor indepen- } \\
\text { den dari respons terhadap terapi } \\
\text { dalam analisis multivariat. Terlip- } \\
\text { ressin dan albumin efektif } \\
\text { digunakan untuk intervensi terapi } \\
\text { HR-1. }\end{array}$ & $\begin{array}{l}\text { Cohort } \\
\text { study }\end{array}$ \\
\hline
\end{tabular}

\section{BAHASAN}

Berdasarkan lima artikel mengenai penegakan diagnosis HRS, diketahui bahwa insidensi HRS relatif tinggi, yaitu sebesar $38,1 \%$ dari seluruh kasus AKI. Angka kematian dari kasus ini pun relatif tinggi, yaitu $64,5 \%$, meskipun telah mendapatkan terapi di rumah sakit. Tidak didapatkan perbedaan angka kematian antara setiap stadium HRS-AKI. Diagnosis HRS ditegakkan menggunakan kriteria diagnosis yang kemudian diklasifikasikan menjadi tiga kelompok. Awalnya, diagnosis HRS diklasifikasikan menjadi dua, yaitu HRS tipe 1 dan HRS tipe 2, tetapi revisi terbaru menunjukkan bahwa HRS diklasifikasikan menjadi tiga kelompok, yaitu hepatorenal syndrome dengan acute kidney injury (HRS-AKI), hepatorenal syndrome dengan acute kidney disease (HRS-AKD), dan hepatorenal syndrome dengan chronic kidney disease (HRS-CKD).$^{6-10}$ Kriteria diagnosis untuk masing-masing klasifikasi tersebut ialah sebagai berikut:

Kriteria diagnosis HRS AKI: ${ }^{6-10}$

1. Peningkatan kreatinin serum sebesar $0,3 \mathrm{mg} / \mathrm{dL}$ dalam waktu 48 jam ATAU peningkatan kreatinin serum $>1,5$ kali dari baseline (nilai kreatinin terbaru dalam 3 bulan terakhir)

2. Tidak ada respons terhadap penghentian diuretik dan tantangan cairan selama 2 hari dengan albumin 20-25\% pada dosis $1 \mathrm{gr} / \mathrm{kgBB} / \mathrm{hari}$

3. Sirosis dengan asites

4. Tidak adanya syok

5. Tidak ada penggunaan obat nefrotoksik baru-baru ini 
6. Tidak ada tanda-tanda cedera ginjal struktural

7. Tidak adanya proteinuria

8. Tidak adanya hematuria

9. Temuan normal pada USG ginjal

Kriteria diagnosis HRS-AKD:

- Perkiraan laju filtrasi glomerulus <60 $\mathrm{mL} / \mathrm{menit} / 1,73 \mathrm{~m}^{2}$ selama $<3$ bulan jika tidak ada penyebab potensial penyakit ginjal lainnya ATAU persentase peningkatan kreatinin serum $<50 \%$ dari baseline

Kriteria diagnosis HRS-CKD:

- Perkiraan laju filtrasi glomerulus <60 $\mathrm{mL} / \mathrm{menit} / 1,73 \mathrm{~m}^{2}$ selama $>3$ bulan tanpa adanya penyebab potensial penyakit ginjal lainnya

Tabel 2 memperlihatkan gambaran distribusi masing-masing literatur berdasarkan analisis PICOS framework. Berdasarkan literatur yang telah ditinjau, didapatkan distribusi rerata usia termuda pasien HRS dari penelitian Sarwar dan Khaan ${ }^{15}$ yaitu 53,3 tahun, sedangkan median (nilai tengah) usia tertua berasal dari penelitian Cavallin et $\mathrm{al}^{12}$ yaitu 65 tahun untuk pasien HRS. Pada kelima literatur didapatkan jenis kelamin laki-laki yang mendominasi sampel penelitian (50-79\%). Untuk tatalaksana terapi pada sampel bervariasi namun, didominasi oleh pemberian terapi terlipressin plus albumin, kemudian pada hasil terapi pasien juga diketahui efektif pada pemberian terlipressin plus albumin. Penelitian Boyer et $\mathrm{al}^{11}$ tahun 2015 menyatakan bahwa pembalikan HRS dicapai pada 23 dari 97 $(23,7 \%)$ pasien yang menerima terlipressin dibandingkan 15 dari 99 (15,2\%) yang mene-rima plasebo $(p=0,13)$.

Penelitian Cavallin et al ${ }^{12}$ tahun 2015 menyatakan bahwa terdapat tingkat pemulihan fungsi ginjal yang lebih tinggi secara bermakna pada kelompok TERLI (19/27, $70,4 \%$ ) dibandingkan kelompok MID/OCT $(6 / 21,28.6 \%), p=0,01$. Peningkatan fungsi ginjal dan penyakit hati dikaitkan dengan kelangsungan hidup yang lebih baik.

Penelitian dari Cavallin et al $^{13}$ tahun 2016 menyatakan bahwa tingkat efek samping lebih rendah pada kelompok
TERLI-INF $(35,29 \%)$ dibandingkan kelompok TERLI-BOL $(62,16 \%, \mathrm{p}<0,025)$. Tingkat respons terhadap pengobatan lengkap dan parsial tidak berbeda bermakna antara kedua kelompok (76,47\% versus $64,85 \%$; nilai $p$ tidak bermakna). Rerata dosis efektif terlipressin harian lebih rendah pada kelompok TERLI-INF dibandingkan kelompok TERLI-BOL.

Hasil penelitian Stine et $\mathrm{al}^{14}$ tahun 2018 menyatakan bahwa rerata skor MELD ialah 26,5 $\pm 7,4$ untuk perempuan dan 58,3\% untuk laki-laki. Keseluruhan kohort 30- dan kelangsungan hidup 180 hari ialah 58,3\% dan 33,3\%. Dua subjek menjalani transplantasi hati. Resolusi HRS-1, respon pengobatan parsial, perubahan kreatinin, kelangsungan hidup 30 hari dan kelangsungan hidup 180 hari serupa antara dua kelompok. Efek samping serius yang memerlukan penghentian pengobatan jarang terjadi $(n=1, P T X)$.

Penelitian Sarwar dan Khan ${ }^{15}$ tahun 2016 menyatakan bahwa respon menyeluruh terhadap terlipressin/albumin terlihat pada $14(58,3 \%)$ pasien, $7(29,2 \%)$ mencapai respon parsial dengan penurunan kreatinin $>25 \%$ sementara $3(12,5 \%)$ tidak memberi respon. Penurunan serum kreatinin saat diagnosis, tidak adanya hiperkalemia dan tidak adanya vena portal trombosis berhubungan dengan respons terhadap pengobatan pada pasien HRS. Kreatinin serum dasar merupakan prediktor independen dari respons terhadap terapi dalam analisis multivariat.

\section{SIMPULAN}

Penegakan diagnosis HRS diklasifikasikan menjadi 3 kelompok, yaitu HRS-AKI, HRS-AKD, dan HRS-CKD. Masing-masing klasifikasi tersebut memiliki kriteria diagnosis yang khas berdasarkan nilai kreatinin serum dan laju filtrasi glomerulus. Terdapat beberapa tatalaksana yang dapat digunakan untuk HRS, yaitu tatalaksana umum, tindakan invasif dan terapi medikamentosa antara lain terlipressin, oktreotida, midodrine, albumin, pentoxifylline, serta berbagai kombinasi terapi tersebut.

Bagi penelitian selanjutnya agar memperhatikan penggunaan laporan penelitian 
yang mencantumkan karakteristik subjek penelitian pada laporan penelitiannya sekaligus menganalisis karakteristik tersebut.

\section{Konflik Kepentingan}

Penulis menyatakan tidak terdapat konflik kepentingan dalam studi ini.

\section{DAFTAR PUSTAKA}

1. World Health Organization. GHE2016_ Deaths_Global_2000_2016 [Internet]. 2018. 2016. Available from: http:// www.who.int/healthinfo/global_burden _disease/estimates/en/

2. Patasik YZ, Waleleng BJ, Wantania F. Profil Pasien Sirosis Hati Yang Dirawat Inap Di Rsup Prof. Dr. R. D. Kandou Manado Periode Agustus 2012 Agustus 2014. e-CliniC. 2015;3(1):3-8.

3. Heidelbaugh JJ, Sherbondy M. Cirrhosis and chronic liver failure: Part II. Compli cations and treatment. American Family Physician. 2006;74:756.

4. Riyanto BS, Wulan HR, Hisyam B. Nafrourologi (Bab 25). In: Buku Ajar Ilmu Penyakit Dalam Jilid II. Jakarta: InternaPublishing, 2014.; p. 2178, 2180, 2182-3.

5. Anindito G. Gambaran klinis pasien sirosis hepatis dengan sindroma hepatorenal pada instalasi rawat inap penyakit dalam RSUD dr Soetomo. 2016; Available from: http://repository.unair.ac.id/ 52385/13/8. 52385.pdf

6. Xiong J, Pu L, Xiong H, Xiang P, Zhang M, Liu $J$, et al. Evaluation of the criteria of hepatorenal syndrome type of acute kidney injury in patients with cirrhosis admitted to ICU. Scand J Gastroenterol. 2018;53(12):1590-6.

7. Acevedo JG, Cramp ME. Hepatorenal syndrome: Update on diagnosis and therapy. World J Hepatol. 2017;9:293-9.

8. Simonetto DA, Gines P, Kamath PS. Hepato- renal syndrome: pathophysiology, diagnosis, and management. BMJ (Clinical research ed.). NLM (Medline); 2020; 370:m2687.

9. De Mattos ÂZ, De Mattos AA, MéndezSánchez N. Hepatorenal syndrome: current concepts related to diagnosis and management. Ann Hepatol. 2016;15(4): 474-81.

10. Angeli P, Garcia-Tsao G, Nadim MK, Parikh CR. News in pathophysiology, defini-tion and classification of hepatorenal syndrome: A step beyond the International Club of Ascites (ICA) consensus document. J Hepatol. 2019;71:811-22.

11. Boyer TD, Sanyal AJ, Wong F, Frederick RT, Lake JR, O'Leary JG, et al. Terlipressin plus albumin is more effective than albumin alone in improving renal function in patients with cirrhosis and hepatorenal syndrome type 1. Gastro-enterology. 2016;150(7):1579-89.e2.

12. Cavallin M, Kamath PS, Merli M, Fasolato S, Toniutto P, Salerno F, et al. Terlipressin plus albumin versus midodrine and octreotide plus albumin in the treatment of hepatorenal syndrome: A randomized trial. Hepatology. 2015;62(2):567-74.

13. Cavallin M, Piano S, Romano A, Fasolato S, Frigo AC, Benetti G, et al. Terlipressin given by continuous intravenous infu-sion versus intravenous boluses in the treatment of hepatorenal syndrome: a randomized controlled study. Hepatology. 2016;63(3):983-92.

14. Stine JG, Wang J, Cornella SL, Behm BW, Henry Z, Shah NL, et al. Treatment of type-1 hepatorenal syndrome with pentoxifylline: a randomized placebo controlled clinical trial. Ann Hepatol. 2018;17(2):300-6.

15. Sarwar S, Khan AA. Hepatorenal syndrome: Response to terlipressin and albumin and its determinants. Pakistan J Med Sci. 2016;32(2):274-8. 